\title{
Successful Management of Pre Partum Cervico-Vaginal Prolapse Concurrent with Dystocia Due to Incomplete Cervical Dilatation in Surti Buffalo: A Case Report
}

\section{Ruchika R Sangle, Maheshkumar V Ingawale*, S G Deshmukh and C H Pawshe}

Department of Animal Reproduction Gynacology and Obstetrics, Postgraduate Institute of Veterinary and Animal Science, Akola, India

*Corresponding Author: Maheshkumar V Ingawale, Department of Animal Reproduction Gynacology and Obstetrics, Postgraduate Institute of Veterinary and Animal Science, Akola, India.

DOI: 10.31080/ASVS.2022.04.0330
Received: January 17, 2021

Published: February 17, 2022

(C) All rights are reserved by Maheshkumar V Ingawale., et al.

\begin{abstract}
The present paper reports the successful treatment of cervico-vaginal prolapse and dystocia due to incomplete cervical dilation in buffalo. Eight-year-old Surti buffalo in fourth parity was presented with history of full term gestation, unproductive straining and severe degree cervico- vaginal prolapse from past $24 \mathrm{hrs}$. The cervico-vaginal prolapse was repositioned and per-vaginal examination discovered one finger cervical dilation whereas foetus was in anterior presentation examined by per rectal examination. The buffalo was treated for incomplete cervical dilation with dexamethasone $40 \mathrm{mg}$, cloprostenol sodium $500 \mu \mathrm{g}$ and intravenous valethamate bromide $80 \mathrm{mg}$ with periodical fathering of cervix. There was cervical dilation and dead fetus was removed with slight traction. The cervico-vaginal prolapse as well as incomplete cervical dilation during parturition in Surti buffalo was successfully managed.
\end{abstract}

Keywords: Cervico-Vaginal Prolapse; Dystocia; Incomplete Cervical Dilation

\section{Abbreviation}

ICD: Incomplete Cervical Dilatation; CVP: Cervico Vaginal Prolapse; CMC: Carboxymethyl Cellulose

\section{Introduction}

Buffalos are backbone for milk production contributing $49 \%$ milk produced in India (Annual Report, DAHD-2020-21). The reproductive concert of buffalos is underprivileged due to numerous diseases of reproductive system which includes genital prolapse $[2,13]$. Cervico-vaginal prolapse typically comprise overhang of the portion of floor, lateral walls and roof of vagina along with cervix and uterus [12]. It is a routine obstetrical delinquent which unfavorably disturbs productive and reproductive performance by upsetting postpartum return to estrus, reducing conception rate and increase in calving interval. Aetiologic features of prepartum cervico-vaginal prolapse in buffalos happens due to nutritional imbalance $[1,8]$, hormonal disproportion [4], seasonal managemen- tal factors [9] and genetic predisposition [10].

Cervico-vaginal prolapse is associated with incomplete cervical dilatation (ICD) that leads to dystocia and the frequency of ICD in cattle and buffaloes were 5.1\% [11]. It happens because of changed endocrine status during birth. Cervico-vaginal prolapse (CVP) is interceded by augmented circulating attentions of estrogens and relaxin during last trimester of gestation leading to relaxation and softening of pelvic ligaments and nearby soft tissue structure [14]. It is intensified by the constant straining by buffalo and partial opening of cervix. The current article reports a case of pre-partum cervico- vaginal prolapse complicated due to incomplete cervical dilatation and leads to dystocia.

\section{Case history and clinical observations}

Eight years old Surti buffalo in fourth parity and in last month of gestation was initially reported with problem of intermittent prolapse of vagina, with vagina protruding from vulva when animal 
was lying down. Further it become aggravated in sequence of period with vaginal mass prolapsed through standup posture while trying to urinate or defecate or strain.

After 15 days, the complete vagina prolapsed and medical inspection exposed inflamed, edematous and congested vaginal mucosa with visible cervix at caudal part. After prolapsed mass originated out animal had non-productive straining. Gross inspection of buffalo displayed relaxed pelvic ligaments and developed udder. All vital parameters were within the standard array.

\section{Treatment and Discussion}

Buffalo was administered with epidural anaesthesia with $2 \%$ lignocaine (LOX ${ }^{\circledR}$, Neon Labs, India) at dose rate of $1 \mathrm{ml}$ for $100 \mathrm{~kg}$ body weight to decrease straining. Then, the prolapsed mass was cleaned with potassium permanganate solution (1:1000 dilution) then icepacks, sugar solution and Popin spray was applied to reduce edema and volume of the mass. Carboxy methyl cellulose (CMC) solution was done over the prolapsed mass. Urine was removed using sterile stainless-steel catheter and future the prolapsed mass was relocated and applied rope truss. Buffalo was soothed with analgesic inj. Meloxicam $15 \mathrm{ml}$, antibiotic Amoxicilline - clavulanic acid - $15 \mathrm{mg} / \mathrm{kg}$ body wt. along with six liters of fluid. Additionally, calcium borogluconate $250 \mathrm{ml} \mathrm{I/V}$ was also administered [3].

After 24 hours there was no dilatation of cervix, and for incomplete cervical dilatation (ICD) treatment consisted of intramuscular injections of dexamethasone $40 \mathrm{mg}$. cloprostenol $500 \mu \mathrm{g}$. and intravenous valethamate bromide $80 \mathrm{mg}$ with periodical fathering of cervix was carried out. Per-vaginal inspection $8 \mathrm{hr}$ posttreatment exposed 4 finger dilation along with suckling reflex of the foetus and cervical massage was repeated. About 4 hour post therapy, chorioallantoic sac appeared at the external os of the cervix through the prolapsed mass that ruptured spontaneously due to movement of animal. Since, cervical dilation was inadequate even after 10 hour intravenous valethamate bromide $50 \mathrm{mg}$ was repeated along with fathering of cervix. After 6hours of second treatment, the buffalo delivered a dead male fetus with mild obstetrical intervention. Fetal membranes were expelled after 5 - 6 hours. Post-partum the buffalo was normal and alert and arranged with routine antibiotics and supportive therapy [11].

Influencing factors include augmented intra-abdominal pressure associated with enlarged size of pregnant uterus, intra-abdominal fat or rumen distention overlaid upon relaxation and soft- ening of the pelvic girdle and associated soft-tissue structures in the pelvic channel and perineum mediated by increased circulating concentrations of estrogens and relaxin during late gestation $[6,7]$. Dystocia due to incomplete cervical dilation occurs because of changes in activation of inflammatory mediators like cytokines along with different endocrinal situation during the process of birth. In the current circumstance, combination of cervical massage [5] along with use of valethamate bromide and PGF2 $\alpha$ resulted in effective dilatation of cervix as reported earlier in cattle and buffalo $[3,11]$. Newly, intracervical application of misoprostol (PGE1 analogue) has been stated in cattle and goat [2] with ICD. Augmented concentration of estrogen because relaxation and softening of the pelvic ligaments along with increased intra-abdominal heaviness might predisposed to cervico-vaginal prolapse. The foetus might be died due to long asphyxia caused by rupture of water bag and incomplete cervical dilatation.

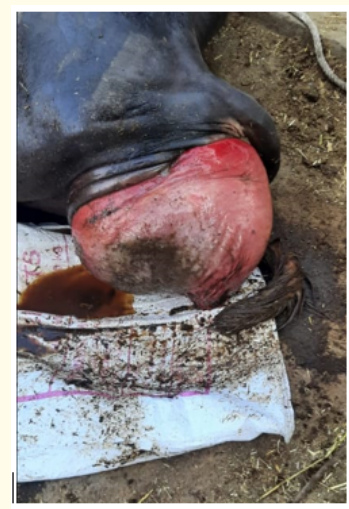

Figure 1: Prolapsed Mass.

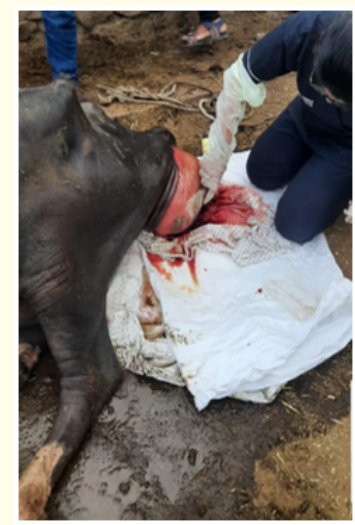

Figure 2: Cleaning of Proplapsed Mass. 


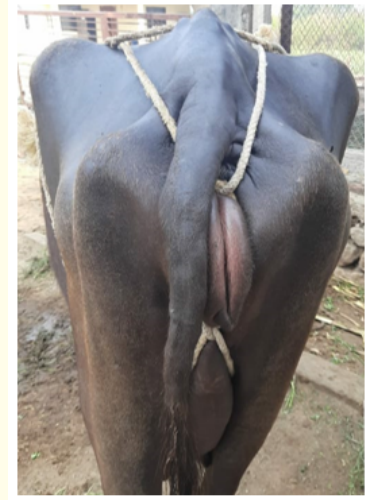

Figure 3: Applied Ropetruss after prolapse reposition.

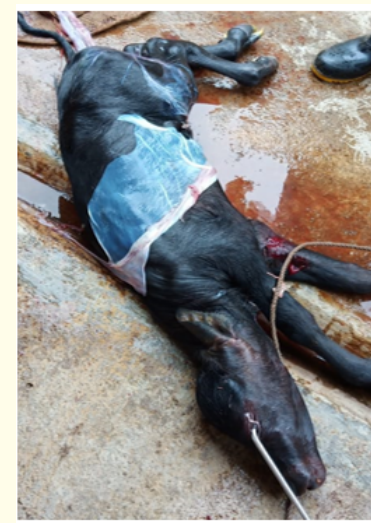

Figure 4: Male Dead Fetus.

\section{Conclusion}

Cervico-vaginal prolapse occurs more commonly in buffalo. There are number of factors which involve in the course of parturition in synergistic mechanism to deliver the fetus. Any deviation or alteration in any factor leads to abnormal condition like prolapse in pre partum period or dystocia. The similar condition incomplete cervical dilatation come in midway during parturition and eventually animal suffers from dystocia. It not only hampers the health of animal but also inflicts the economy of the farm severely. So, the animal should be provided proper care and management and urgent medication during the pre-parturient period to avoid such type of conditions.

\section{Bibliography}

1. Ahmed SI., et al. "Clinical, haematological and serum macro mineral contents in buffaloes with genital prolapse". The Pakistan Veterinary Journal 25 (2005): 167-170.

2. Akhtar MS., et al. "Serum ovarian steriod hormones and some minerals concentration in pregnant Nili-Ravi buffaloes with or without pre-partum vaginal prolapse". The Pakistan Veterinary Journal 32 (2012): 265-268.

3. Das GK., et al. "Incomplete cervical dilatation causing dystocia in a buffalo". Indian Journal of Veterinary Research 17.2 (2008): 41-43.

4. Galhotra MM., et al. "FSH, LH and prolactin in antepartum vaginal prolapse of buffaloes (Bubalusbubalis) in relation to cortisol and degree of stress". The Indian Veterinary Journal 68 (1991): 332-335.

5. Honparkhe M., et al. "Cervical massage with sodium carboxy methyl cellulose for achieving complete cervical dilatation in successfully detorted uterine torsion affected buffaloes". Indian Journal of Animal Science 79 (2009): 26-29.

6. Hanie EA. "Prolapse of the Vaginal and Uterus: Textbook of Large Animal Clinical Procedures for Veterinary Technicians". Elsevier, Mosby 68 (2006): 332-335.

7. Jackson PGG., et al. "Post-parturient Problems in Large Animals". Handbook of Veterinary Obstetrics, Elsevier Saunders 2nd edition (2004).

8. Kelkar MA., et al. "Studies on the ante partum prolapse of the vagina in buffaloes and plasma trace element concentrations". Archiv für experimentelle Veterinärmedizin 43 (1989): 315318.

9. Mishra UK., et al. "Incidence of prolapse of genitalia in Murrah buffaloes in relation to season, pregnancy, parity and management". The Indian Veterinary Journal 75 (1998): 254-255.

10. Nanda AS and RD Sharma. "Incidence and etiology of pre-partum prolapse of vagina in buffaloes". Indian Journal of Dairy Science 35 (1982): 168-171.

11. Purohit GN., et al. "Maternal dystocia in cows and buffaloes: a review". Open Journal of Animal Sciences 1 (2011): 41-53.

12. Robert's SJ. “Diseases of the puerperal period In Veterinary Obstetrics and Genital Diseases". CBS Publishers and Distributors, Delhi, India (1971): 303-313. 
13. Rao AVN and O Sreemannarayana. "Clinical analysis of reproductive failureamong female buffaloes (Bubalus bubalis) under village management in Andhra Pradesh". Theriogenology 18 (1983): 403-411.

14. Wolfe DF. "Medical and surgical management of vaginal prolapse in cattle". In Proceedings of 81st Annual WesternVeterinary Conference, USA (2009).

\section{Assets from publication with us}

- Prompt Acknowledgement after receiving the article

- Thorough Double blinded peer review

- Rapid Publication

- Issue of Publication Certificate

- High visibility of your Published work

Website: $\underline{w w w}$.actascientific.com/

Submit Article: www.actascientific.com/submission.php

Email us: editor@actascientific.com

Contact us: +919182824667 